\title{
The yexA gene product is required for phosphoribosylformylglycinamidine synthetase activity in Bacillus subtilis
}

\author{
Hans H. Saxild ${ }^{1}$ and Per Nygaard ${ }^{2}$ \\ Author for correspondence: Hans H. Saxild. Tel: +45 2524 95. Fax: +45882660. \\ e-mail:imhhs@pop.dtu.dk
}

\begin{abstract}
1 Department of Microbiology, Technical University of Denmark, Building 301, DK-2800 Lyngby, Denmark

2 Department of Biological Chemistry, Institute of Molecular Biology, University of Copenhagen, Sølvgade 83, DK-1307 Copenhagen, Denmark
\end{abstract}

\begin{abstract}
The yexA gene encodes an 84 amino acid reading frame; in Bacillus subtilis it is positioned between the purC and purQ genes of the purine biosynthetic operon. Disruption of yexA resulted in a purine-auxotrophic phenotype. When yexA was expressed in trans it was able to complement a yexA mutation. Growth experiments and enzyme analysis of yexA mutant strains revealed a defective phosphoribosylformylglycinamidine synthetase (FGAM synthetase). In the organisms in which FGAM synthetase has been studied a single polypeptide is responsible for activity. In some organisms two separate genes - in B. subtilis the purL and purQ genes - encode polypeptides with similarity to the $\mathrm{N}$-terminal and the $\mathrm{C}$-terminal region, respectively, of the singlepolypeptide FGAM synthetase. Thus, active FGAM synthetase in B. subtilis requires the yexA gene product in addition to the purL and purQ gene products. Open reading frames with sequence similarity to yexA are found in other Gram-positive organisms, in a cyanobacterium and in methanogenic archaea. The designation purS is proposed for this novel function in purine biosynthesis in B. subtilis.
\end{abstract}

Keywords: yexA, purine biosynthesis, purS, Bacillus subtilis, FGAM synthetase

\section{INTRODUCTION}

The formation of inosine monophosphate (IMP) from 5'-phosphoribosyl 1'-pyrophosphate (PRPP) proceeds through an 11-step enzyme-catalysed pathway known as the de novo purine biosynthetic pathway. The fourth step in biosynthesis of purines is catalysed by the enzyme phosphoribosylformylglycinamidine (FGAM) synthetase (EC 6.3.5.3), which catalyses the reaction $5^{\prime}$-phosphoribosylformylglycinamide (FGAR) + glutamine + ATP $\rightarrow$ FGAM + glutamate $+\mathrm{ADP}+\mathrm{P}_{\mathrm{i}}$. Functional FGAM synthetases purified from chicken liver, Salmonella typhimurium and Escherichia coli consist of monomeric polypeptides of $133 \mathrm{kDa}, 135 \mathrm{kDa}$ and $141 \mathrm{kDa}$, respectively (Schendel et al., 1989). Antibodies raised against FGAM synthetase from Chinese hamster ovary cells cross-react with a human protein with a molecular mass of $150 \mathrm{kDa}$ (Barnes et al., 1994).

The E. coli FGAM synthetase is encoded by the purL

Abbreviations: FGAM, phosphoribosylformylglycinamidine; FGAR, 5'-phosphoribosylformylglycinamide; GAR, phosphoribosylglycinamide; sAMP, adenylosuccinate. gene. The PurL polypeptide contains two domains, an N-terminal ATPase domain and a C-terminal glutamine-binding domain (Schendel et al., 1989). Nucleotide sequence analysis of the pur operon of Bacillus subtilis indicated that FGAM synthetase in this organism is encoded by two genes, purQ and purL (Ebbole $\&$ Zalkin, 1987). Alignment of the primary structure of the E. coli FGAM synthetase and the structure of the $B$. subtilis $\mathrm{Q}$ and $\mathrm{L}$ subunits showed that the PurQ sequence is homologous to the C-terminal part and the purL sequence is homologous to the N-terminal part of the $E$. coli PurL sequence. This indicated that the $\mathrm{N}$ - and $\mathrm{C}$ terminal domains of FGAM synthetase in B. subtilis are located on separate proteins.

The B. subtilis pur operon has the gene order purE, $K, B$, $C, y e x A, Q, L, F, M, N, H$ and $D$ (Ebbole \& Zalkin, 1987). The different genes are organized in groups with overlapping coding regions: purE $-K-B$; purC-yexApurQ $-L-F$; pur $M-N-H$; and purD. The open reading frame designated yexA located immediately upstream of pur $Q$ encodes an unknown function. yex $A$ has a reading frame that overlaps with both purC and purQ. In this report we present evidence that FGAM synthetase in $B$. 
Table 1. Bacterial strains, plasmids and $P C R$ primers

\begin{tabular}{|c|c|c|}
\hline $\begin{array}{l}\text { Strain/plasmid/ } \\
\text { PCR primer }\end{array}$ & Characteristics & Reference, source or coordinates* \\
\hline \multicolumn{3}{|l|}{ B. subtilis } \\
\hline 168 & $\operatorname{trp} C 2$ & $\begin{array}{l}\text { C. Anagnostopoulos, CNRS, } \\
\text { Jouy-en-Josas, France }\end{array}$ \\
\hline BFA2257 & $\operatorname{trp} C 2$ yexA::pMutin1 (erm) & $\begin{array}{l}\text { Transformation of } 168 \text { by } \\
\text { pHH1053, Er }\end{array}$ \\
\hline НH306 & $\operatorname{trp} C 2$ yexA::pHH1059 (cat) & $\begin{array}{l}\text { Transformation of } 168 \text { by } \\
\text { pHH1059, } \mathrm{Cm}^{\mathrm{R}}\end{array}$ \\
\hline HН309 & $\operatorname{trp} C 2$ yexA6 & HH306 screened for $\mathrm{Cm}^{\mathrm{s}}$ \\
\hline HH330 & trpC2 yexA6 amyE::pDG268 (neo) & $\begin{array}{l}\text { Transformation of } \mathrm{HH} 309 \text { by } \\
\text { pDG268neo digested with KpnI, } \\
\mathrm{Neo}^{\mathrm{R}}\end{array}$ \\
\hline HH332 & $\operatorname{trpC2}$ yexA6 amyE::pDG268 (neo)::pHH1091 (yexA $\left.A^{+}\right)($erm) & $\begin{array}{l}\text { Transformation of } \mathrm{HH} 330 \text { by } \\
\text { pHH1091, } \mathrm{Er}^{\mathrm{R}}\end{array}$ \\
\hline ED148 & $\operatorname{trp} C 2$ purM & CU869 (Saxild \& Nygaard, 1988) \\
\hline ED249 & trpC2 hisA1 thr-5 purL1 & Saxild \& Nygaard (1988) \\
\hline \multicolumn{3}{|l|}{ E. coli } \\
\hline MC1061 & $\begin{array}{l}\mathrm{F}^{-} \text {araD139 } \Delta(\text { ara-leu }) 7696 \text { galE15 galK16 } \Delta(\text { lac }) \text { X74 rpsL } \\
\left(\mathrm{Str}^{\mathrm{R}}\right) \text { hsdR2 }\left(\mathrm{r}^{-} \mathrm{m}^{-}\right) \text {mcrA mcrB }\end{array}$ & Laboratory stock \\
\hline \multicolumn{3}{|l|}{ Plasmids } \\
\hline pMutin1 & $\begin{array}{l}\mathrm{Ap}^{\mathrm{R}} \text { (E. coli), } \mathrm{Er}^{\mathrm{R}} \text { (B. subtilis); integrational vector for } \\
\text { knockout mutations and formation of transcriptional lac } Z \\
\text { fusion; the IPTG-inducible } \mathrm{P}_{\text {spac }} \text { promoter is introduced to } \\
\text { ensure expression of downstream genes }\end{array}$ & Vagner et al. (1998) \\
\hline pDG268neo & $\begin{array}{l}\operatorname{Ap}^{\mathrm{R}} \text { (E. coli), Neo }{ }^{\mathrm{R}} \text { (B. subtilis); vector used for integration of } \\
\text { transcriptional lacZ fusions into the amyE gene of B. subtilis }\end{array}$ & Saxild et al. (1996) \\
\hline pBOE335 & $\begin{array}{l}\mathrm{Ap}^{\mathrm{R}} \text { (E. coli) } \mathrm{Cm}^{\mathrm{R}} \text { (B. subtilis); integrational vector, pUC19 } \\
\text { containing the cat gene cloned into the KasI site }\end{array}$ & Saxild et al. (1996) \\
\hline pHH1053 & $\begin{array}{l}\text { pMutin1 digested with Bam HI and HindIII ligated to a } 156 \mathrm{bp} \\
\text { PCR fragment (primers } 07+08 \text { ) digested with the same } \\
\text { enzymes }\end{array}$ & This work \\
\hline pHH1059 & $\begin{array}{l}\text { pBOE335 digested with EcoRI and Pst I and ligated to a } 399 \text { bp } \\
\text { PCR fragment (primers } 01+02 \text { ) digested with Pst I and } \\
\text { Bam HI and to a PCR fragment (primers } 03+04 \text { ) digested } \\
\text { with EcoRI and BamHI }\end{array}$ & This work \\
\hline pHH1091 & $\begin{array}{l}\text { pMutin1 digested with HindIII and BamHI and ligated to a } \\
1040 \text { bp PCR fragment (primers } 05+06 \text { ) digested with the } \\
\text { same enzymes; this cloning brings yexA expression under the } \\
\text { control of the IPTG-inducible } \mathrm{P}_{\text {spac }} \text { promoter }\end{array}$ & This work \\
\hline \multicolumn{3}{|l|}{ PCR primers $\dagger$} \\
\hline Primer 01 & 5'-GCCCTGCAGAAGGCACGGAGCTTGAG-3† & $701444-701460$ \\
\hline Primer 02 & 5'-GCGGGATCCTTACTTTATACATGATGAATGCC-3' & $701843-701821$ \\
\hline Primer 03 & 5'-GCGGGATCCAGGTTGAGGAGGTAGTCG-3' & $702060-702077$ \\
\hline Primer 04 & 5'-CCGGAATTCATTCTCCCTTTTCGTAGG-3' & $702484-702468$ \\
\hline Primer 05 & 5'-GCCGAAGCTTAAGGCACGGAGCTTGAG-3' & $701444-701460$ \\
\hline Primer 06 & 5'-GCGGGATCCATTCTCCCTTTTCGTAGG-3' & $702484-702468$ \\
\hline Primer 07 & 5'-GCCGAAGCTTCTAGATCCACAAGGGAG-3' & $701873-701891$ \\
\hline Primer 08 & 5'-GCGGGATCCCAAGAAGTTTTTCGCAC-3' & $702029-702013$ \\
\hline
\end{tabular}

* Coordinates were taken from the B. subtilis genome sequence (Kunst et al., 1997).

†Underlined sequence indicates the position of the restriction site.

subtilis (and most likely also in several other organisms), in addition to the PurQ and PurL subunits, also requires the presence of the yexA gene product for activity.

\section{METHODS}

Bacterial strains, growth media and growth conditions. Bacterial strains and plasmids used in this work are listed in 


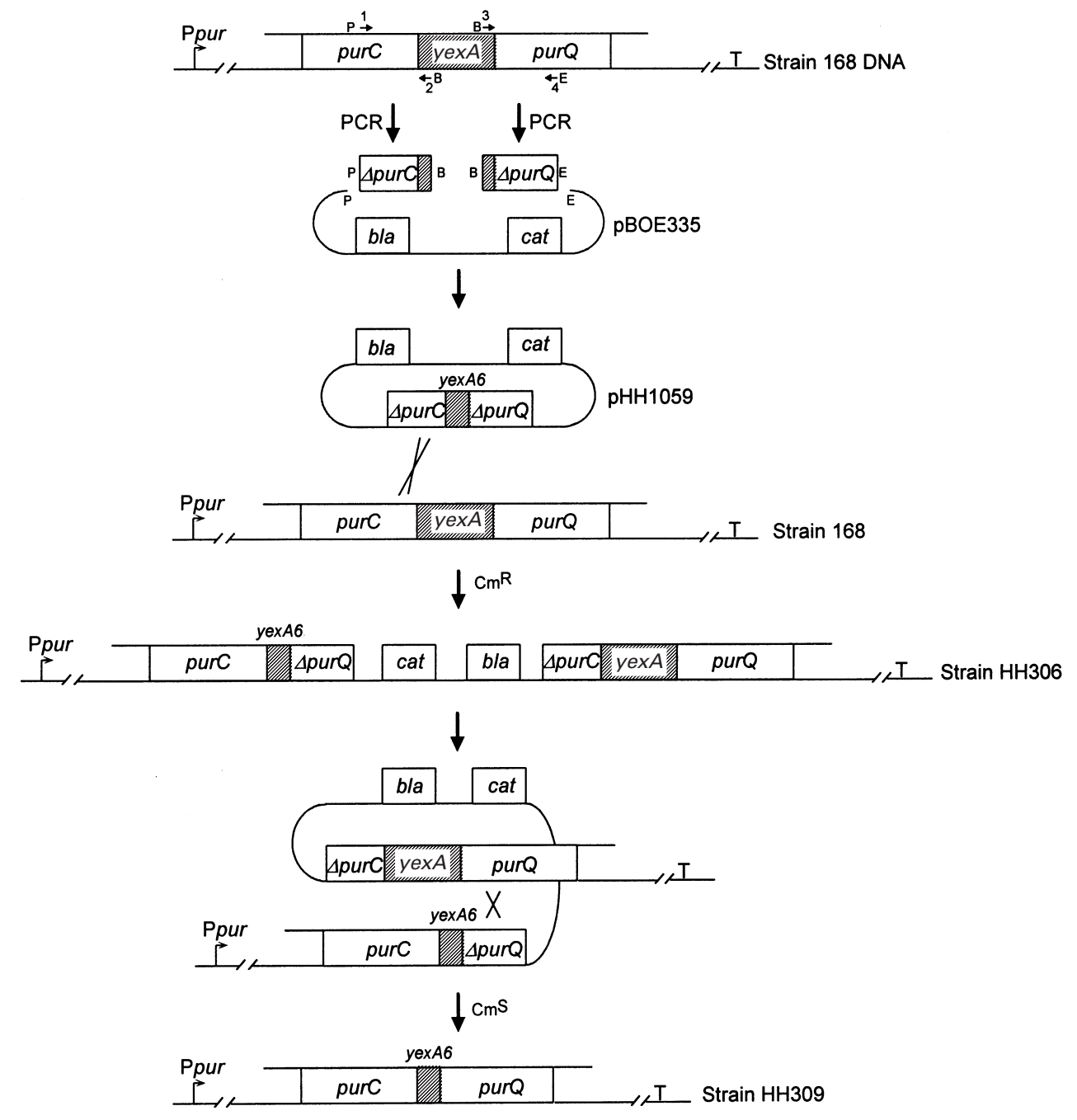

Fig. 1. Creation of the yexA6 in-frame deletion mutation and the strategy used to recombine the mutation into the pur locus of the $B$. subtilis chromosome. The relevant part of the pur operon is shown. The genes are not drawn to scale. Symbols: small numbered horizontal arrows indicate the position and orientation of the DNA primers used in the PCR reactions; $\mathrm{B}, \mathrm{BamHI} ; \mathrm{P}$, Pstl; E, EcoRI; $\mathrm{P}$ pur, pur operon promoter; T, transcription terminator; purC, phosphoribosylaminoimidazole-succinocarboxamide synthetase; purQ, FGAM synthetase subunit; bla, $\beta$-lactamase; cat, chloramphenicol acetyltransferase.

Table 1. As defined medium for B. subtilis strains, Spizizen'ssalts buffered minimal medium (Saxild \& Nygaard, 1987) supplemented with $40 \mathrm{mg}$ L-tryptophan $\mathrm{l}^{-1}, 1 \mathrm{mg}$ thiamin. $\mathrm{HCl}$ $1^{-1}, 0 \cdot 2 \%$ L-glutamate and $0 \cdot 4 \%$ glucose was used. Where indicated, MOPS-buffered minimal medium was used (Saxild \& Nygaard, 1991). L-broth was used as rich medium. Bacterial strains were cultivated at $37^{\circ} \mathrm{C}$ and growth was measured by determining the $\mathrm{OD}_{450}$. Antibiotics were used at the following final concentrations: ampicillin (Ap), $100 \mu \mathrm{g} \mathrm{ml} \mathrm{g}^{-1}$; chlor-

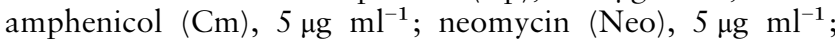
erythromycin (Er), $1 \mu \mathrm{g} \mathrm{ml} \mathrm{g}^{-1}$; lincomycin, $25 \mu \mathrm{g} \mathrm{ml} \mathrm{g}^{-1}$. IPTG and X-Gal were added to a final concentration of $1 \mathrm{mM}$ and $40 \mu \mathrm{g} \mathrm{ml}{ }^{-1}$, respectively.

Enzyme assays and labelling of phosphorylated intermediates of the purine biosynthetic pathway. Preparation of cell-free extracts and measurement of the activities of adenylosuccinate (sAMP) lyase (Saxild \& Nygaard, 1991), phosphoribosylglycinamide (GAR) synthetase (Houlberg et al., 1983) and $\beta$-galactosidase (Miller, 1972) were carried out as pre- viously described. Activity of FGAM synthetase using ${ }^{14} \mathrm{C}$ labelled FGAR was measured essentially as described by Houlberg et al. (1983). Protein was determined by the Lowry method. The intracellular accumulation of intermediates of the purine biosynthetic pathway in purine-starved cells was determined as described before (Saxild \& Nygaard, 1988). Cells were grown in the presence of $0.1 \mathrm{mM}$ xanthine. At $\mathrm{OD}_{450} 0 \cdot 5$, cells were collected by filtration and resuspended in purine-free medium containing $\left[{ }^{32} \mathrm{P}\right]$ orthophosphate. ${ }^{32} \mathrm{P}$ labelled compounds from cells grown for $2 \mathrm{~h}$ in $1 \mathrm{mM}$ phosphate MOPS-buffered minimal medium containing $0.4 \mathrm{MBq}\left[{ }^{32} \mathrm{P}\right]$ orthophosphate $\mathrm{ml}^{-1}$ were extracted with formic acid and separated on polyethyleneimine-impregnated cellulose on plastic sheets as described by Jensen et al. (1979).

DNA manipulations. Isolation of chromosomal DNA (Saxild \& Nygaard, 1987) and plasmid DNA (Birnboim \& Doly, 1972), and transformation of B. subtilis (Boylan et al., 1972) and E. coli (Hanahan, 1983), were carried out by standard methods. Restriction enzyme digestions and alkaline phos- 


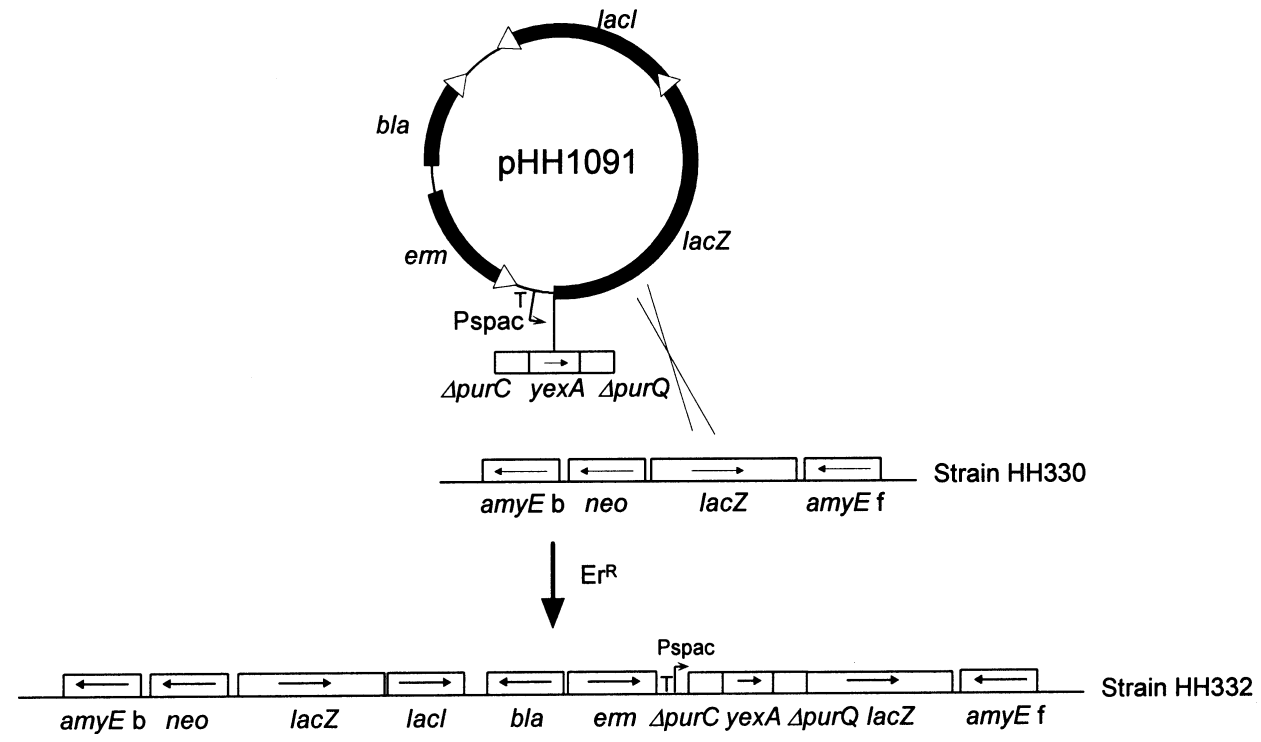

Fig. 2. Recombination of a $\mathrm{P}_{\text {spac }}-y e x A^{+}$construction into the lacZ gene located in the amyE locus in strain $H H 330$ (amyE::pDG268neo yexA6). Symbols: white-headed black arrows indicate plasmid-encoded genes; thin arrows indicate the direction of transcription of the gene in question; erm, erythromycin-resistance gene; neo, neomycin-resistance gene; lacZ, $\beta$-galactosidase; amyEf, $\alpha$-amylase ( $5^{\prime}$ part); amyEb, $\alpha$-amylase (3' part): lacl, $E$. coli lactose operon repressor. The rest of the symbols are defined in the legend to Fig. 1.

phatase treatment were done as recommended by the supplier (Gibco-BRL). For Southern blot analysis, DNA was blotted onto a nitrocellulose membrane (GeneScreen, NEN Research Products). The chemiluminescence labelling and detection kit Southern Light (Tropix, PE Applied Biosystems) was used for light detection of the hybridization products. The recipe supplied by the manufacturer was followed. PCR was done by incubating template DNA with forward and reverse primers $\left(8 \mu \mathrm{g} \mathrm{ml}^{-1}\right.$ each), $0.5 \mathrm{mM} \mathrm{dNTPs}$ and 1 unit Taq polymerase (Amersham Pharmacia Biotech) in $10 \mathrm{mM}$ Tris $\mathrm{pH} 7 \cdot 0$ and $0.5 \mathrm{mM} \mathrm{Mg}^{2+}$. The reactions were run in a Biometra Trio 48 Thermocycler for 30 cycles consisting of $1 \mathrm{~min}$ at $94{ }^{\circ} \mathrm{C}, 1 \mathrm{~min}$ at $55^{\circ} \mathrm{C}$ and $1 \mathrm{~min}$ at $72^{\circ} \mathrm{C}$. The reaction product was purified by centrifugation through a Pharmacia GFX Spin column.

DNA sequencing. Sequencing of double-stranded DNA templates was performed by using the Amersham thermocycle chain-termination sequencing kit containing ${ }^{33} \mathrm{P}$-labelled dideoxynucleotides (Amersham Pharmacia Biotech). Reaction products were separated on a $6 \%$ polyacrylamide gel and visualized by autoradiography.

Construction of an in-frame deletion mutation in yexA. The method used to construct strain HH309 (yexA6) is illustrated in Fig. 1. Two fragments containing the $5^{\prime}$ and the $3^{\prime}$ end of the yex $A$ reading frame, respectively, were generated by PCR. The fragment containing the $5^{\prime}$ end was digested with PstI and $B a m \mathrm{HI}$ and the other fragment was digested with EcoRI and BamHI. The fragments were simultaneously ligated into plasmid pBOE335 digested with PstI and EcoRI. The resulting plasmid, pHH1059, was transformed into B. subtilis strain 168 selecting for $\mathrm{Cm}^{\mathrm{R}}$. Since pBOE335 cannot replicate in $B$. subtilis the plasmid integrates into the chromosome in the pur locus as illustrated in Fig. 1. The resulting strain, HH306, was grown for several generations in the absence of $\mathrm{Cm}$ and plated on L-broth agar plates without $\mathrm{Cm}$. The resulting colonies were then tested on $\mathrm{Cm}$-containing agar plates and $\mathrm{Cm}^{\mathrm{s}}$ clones were isolated. One of the clones (HH309) was chosen, and primers 01 and 04 were used to generate a PCR fragment that covers the yexA region. Sequence analysis of the PCR fragment revealed that the replacement of the wild-type yexA allele with the yexA6 in-frame deletion was successful.

Cloning and expression of yexA from an IPTG-inducible promoter. Primers 05 and 06 (Table 1) were used to generate a 1040 bp PCR fragment containing the $3^{\prime}$ end of the purC gene, the entire yexA reading frame and the $5^{\prime}$ end of the purQ gene. The fragment was ligated into plasmid pMutin1. The resulting plasmid, pHH1091, contains the yexA gene placed after the IPTG-inducible $P_{\text {spac }}$ promoter and in front of the lacZ reporter gene (Vagner et al., 1998) as illustrated in Fig. 2. Plasmid pHH1091 was transformed into strain HH330, which contains the plasmid pDG268neo integrated into the amyE gene. Since no promoter is present in front of the lac $Z$ gene of pGD268, strain HH330 is $\beta$-galactosidase-negative. Because pHH1091 cannot replicate in B. subtilis, $\mathrm{Er}^{\mathrm{R}}$ transformants of strain HH330 will only be formed if recombination between the two identical lac $Z$ sequences or the two identical yexA sequences occurs. Five $\operatorname{Er}^{\mathrm{R}}$ transformants were analysed by Southern blotting and one clone (HH332, Fig. 2) with pHH1091 recombined into the amyE locus was isolated.

\section{RESULTS}

\section{Integration of pMutin1 into the yexA locus and phenotype of a yexA mutant strain}

A $156 \mathrm{bp}$ PCR product internal to the yexA reading frame was amplified by the use of primers 07 and 08 (Table 1). The DNA fragment was digested with HindIII and BamHI and cloned into the HindIII and BamHI sites of plasmid pMutin1, resulting in $\mathrm{pHH} 1053$. Derivatives of plasmid pMutin 1 contain - in addition to a part of the gene to be knocked out, here yex $A$ - the $\mathrm{P}_{\text {spac }}$ promoter under the control of the lacI gene product. The 
promoter drives the transcription of the region downstream of the integration point and can be induced by IPTG (Vagner et al., 1998). Plasmid pHH1053 was integrated into the yexA gene by a single homologous recombination event, which was confirmed by Southern blot analysis (data not presented). When tested for growth on minimal agar plates the resulting strain (BFA2257) had a purine-auxotrophic phenotype both with and without added IPTG. BFA2257 could use hypoxanthine as purine source, which indicates that the purine-negative phenotype was due to a defect in the formation of IMP (Saxild \& Nygaard, 1988).

\section{Isolation and phenotype of a mutant strain containing an in-frame deletion in yexA}

The five genes purC, yexA, purQ, purL and purF have overlapping coding sequences, which might indicate translational coupling (Ebbole \& Zalkin, 1987). Translational coupling means that translation of a certain gene requires the translation of the overlapping upstream gene. In B. subtilis translational coupling has been shown to be important for the expression of the pbuX gene (Christiansen et al., 1997), but has not been demonstrated to function in the expression of genes in the pur operon (Ebbole \& Zalkin, 1989). However, it could not be excluded that the plasmid integration into yexA in BFA2257 affects the translation of the downstream gene purQ and that the purine-negative phenotype was due to $p u r Q$ deficiency and not caused by the disruption of yexA. To test this possibility, an in-frame deletion of 73 codons of the yexA reading frame was constructed and recombined into the chromosome as described in Methods (Fig. 1). The resulting strain, HH309, also showed a purine-negative phenotype. Like BFA2257, HH309 was able to use hypoxanthine as a purine source, indicating a similar defect in both mutant strains.

\section{Identification of the metabolic block in the yexA mutants}

To narrow down the biochemical defect in the yex $\mathrm{A}$ mutants we determined their purine enzyme levels, growth on different purine sources, thiamin requirement, and accumulation of intermediary compounds of the purine biosynthetic pathway under conditions of purine starvation as described before (Saxild \& Nygaard, 1988).

The accumulation studies showed an accumulation of FGAR in the yexA mutant, which indicates a block in the reaction catalysed by FGAM synthetase. The key experiment is shown in Fig. 3. Strain ED249 (purL) accumulated FGAR and ED148 (purM) accumulated both FGAR and FGAM. Strain HH309 (yexA6) accumulated large amounts of FGAR, thus resembling the purL strain ED249. The phenotypic similarity of HH309 to ED249 indicates that FGAM synthetase activity in HH309 is impaired. Strain BFA2257 was subjected to purine starvation in both the presence and absence of

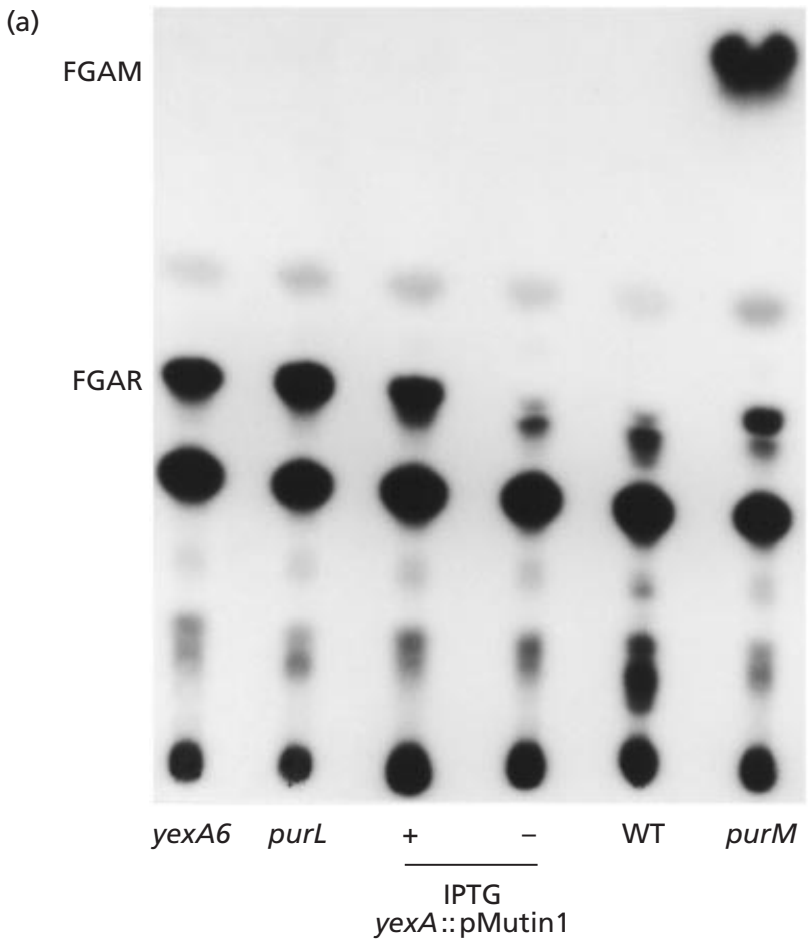

(b)

$$
\begin{aligned}
& \mathrm{PRPP} \rightarrow \mathrm{PRA} \rightarrow \mathrm{GAR} \rightarrow \mathrm{FGAR} \rightarrow \mathrm{FGAM} \rightarrow \mathrm{AIR} \\
& \text { purf purD purN purQL purM }
\end{aligned}
$$

Fig. 3. Autoradiogram of ${ }^{32} \mathrm{P}$-labelled extracts of $B$. subtilis mutant strains starved for purine and outline of the first five steps in $B$. subtilis purine biosynthesis. (a) The ${ }^{32}$ P-labelled intermediates of the purine biosynthetic pathway were separated by thin-layer chromatography as described in Methods. Lane 1, HH309 (yexA6); lane 2, ED249 (purL); lane 3, BFA2257 (yexA::pMutin1)+IPTG; lane 4, BFA2257 - IPTG; lane 5, 168 (wild-type); lane 6, ED148 (purM). (b) Gene-enzyme relationships of the initial five steps of purine biosynthesis. PRPP, phosphoribosylpyrophosphate; PRA, phosphoribosylamine; GAR, phosphoribosylglycinamide; FGAR; phosphoribosyl-formylglycinamide; FGAM, phosphoribosylformylglycinamidine; AIR, phosphoribosylaminoimidazole; purF, phosphoribosylamidotransferase; purD, phosphoribosylglycinamide synthetase; purN, ( $N^{10}$-formyl-THFA)-dependent phosphoribosylglycinamide formyltransferase; purT, formatedependent phosphoribosylglycinamide formyltransferase; purQL, FGAM synthetase subunits; purM, phosphoribosylaminoimidazole synthetase.

IPTG. As mentioned above, IPTG induces the $\mathrm{P}_{\text {spac }}$ promoter, which results in the transcription of genes located downstream of the pMutin1 insertion point (Vagner et al., 1998). In the B. subtilis pur operon the purQ, L, F, M, N, $H$ and $D$ genes are located downstream of yexA (Ebbole \& Zalkin, 1987). When BFA2257 was starved for purine in the absence of IPTG a very low amount of FGAR was produced. Purine starvation in the presence of IPTG resulted in the accumulation of large amounts of FGAR. So in the presence of IPTG BFA2257 is phenotypically FGAM synthetase negative. It can therefore be concluded that 
Table 2. Level of purine biosynthetic enzymes in the wild-type and yexA mutant strains grown in the presence of different purine compounds

Cells were grown in glucose minimal medium supplemented with the stated purine compound (xanthine, $0.1 \mathrm{mM}$; adenine, $1 \mathrm{mM}$; guanosine, $1 \mathrm{mM}$ ) and with or without IPTG. Enzyme activities were determined as described in Methods. The listed values are means of three experiments.

\begin{tabular}{|c|c|c|c|c|c|c|c|}
\hline \multirow[t]{2}{*}{ Strain } & \multirow{2}{*}{$\begin{array}{l}\text { Relevant } \\
\text { genotype }\end{array}$} & \multirow{2}{*}{$\begin{array}{l}\text { Addition to } \\
\text { medium }\end{array}$} & \multirow{2}{*}{$\begin{array}{c}t_{\mathrm{d}}^{*} \\
(\min )\end{array}$} & \multirow[t]{2}{*}{ Gene order and gene expression $†$} & \multicolumn{3}{|c|}{ Enzyme activity $\left[\mathrm{nmol} \mathrm{min}^{-1}(\mathrm{mg} \text { protein })^{-1}\right]$} \\
\hline & & & & & $\begin{array}{c}\boldsymbol{\beta} \text {-Galactosidase } \\
(\text { lac } Z)\end{array}$ & $\begin{array}{l}\text { sAMP } \\
\text { lyase } \\
(p u r B)\end{array}$ & $\begin{array}{c}\text { GAR } \\
\text { synthetase } \\
(p u r D)\end{array}$ \\
\hline \multirow[t]{4}{*}{168} & Wild-type & & & $\mathrm{P}_{\text {pur }}-$ purB-yexA-purD-T & & & \\
\hline & & None & 46 & $\longrightarrow$ & ND & 118 & 13 \\
\hline & & Xanthine & 48 & $\longrightarrow$ & ND & 117 & 18 \\
\hline & & Adenine + Guanosine & 46 & $\longrightarrow$ & ND & 9 & 4 \\
\hline \multirow[t]{4}{*}{ BFA2257 } & yexA:: pMutin1 & & & $\mathrm{P}_{\text {pur }}-$ purB-yexA'-lacZ-T-P ${ }_{\text {spac }}-$ purD-T & & & \\
\hline & & Xanthine & 52 & $\longrightarrow$ & 1578 & 239 & $<1$ \\
\hline & & Xanthine + IPTG & 50 & $\longrightarrow$ & 940 & 194 & 7 \\
\hline & & Adenine + Guanosine & 48 & $\longrightarrow$ & 55 & 16 & $<1$ \\
\hline \multirow[t]{3}{*}{ НH309 } & yexA6 & & & $\mathrm{P}_{\text {pur }}-$ purB- $B$ yexA-purD-T & & & \\
\hline & & Xanthine & 52 & $\longrightarrow$ & ND & 221 & 42 \\
\hline & & Adenine + Guanosine & 48 & $\longrightarrow$ & ND & 12 & 4 \\
\hline \multirow[t]{3}{*}{ HH332 } & yexA6 $\mathrm{P}_{\text {spac }}-y e x A^{+}$ & & & $\mathrm{P}_{\text {pur }}-$ purB-DyexA-purD-T//amyE:: $\mathrm{P}_{\text {spac }}-$ yexA-lacZ-T & & & \\
\hline & & Xanthine & 52 & $\longrightarrow$ & 7 & 235 & 49 \\
\hline & & Xanthine + IPTG & 48 & $\longrightarrow$ & 152 & 125 & 21 \\
\hline
\end{tabular}

ND, Not determined.

$* t_{\mathrm{d}}$, doubling time.

†Only relevant genes are noted. The gene order of the pur operon is $\mathrm{P}_{\text {pur }}-E-K-B-C-y$ ex $A-Q-L-F-M-N-H-D-T$. Arrows indicate the various transcripts formed in the cell under the growth condition in question. $\mathrm{P}$, promoter; $\mathrm{T}$, terminator.

the downstream-located purF, purD and purN genes, which encode the first three steps of the pathway (Fig. 3), are only weakly expressed in the absence of IPTG, but efficiently expressed in the presence of IPTG. If these genes are expressed, purQ and purL are most likely also expressed. However, it could not be exclusively concluded that the accumulation of FGAR in strain HH309 and in BFA2257 grown in the presence of IPTG was due to the lack of the yexA gene product. The possibility that the mutational changes could result in some kind of polar effect on the expression of the downstream-located purQ and purL genes could not be ruled out.

\section{Effects of the yexA mutation on the expression of the pur operon}

The levels of sAMP lyase, encoded by the purB gene located upstream of yexA, and of GAR synthetase, encoded by the purD gene located downstream of yexA, were determined in wild-type strain 168 and the yexA mutant strains BFA2257 and HH332. Two growth conditions were used. In one, xanthine served as the purine source. In this condition purine gene expression is neither derepressed nor repressed. In the other condition adenine and guanosine were added as purine source. In this condition the purine gene expression is maximally repressed (Saxild \& Nygaard, 1991). As expected, enzyme levels in the wild-type were not repressed by xanthine, whereas addition of adenine plus guanosine resulted in reduced enzyme levels (Table 2).
In both mutant strains (BFA2257 and HH309) reduced growth rate in the xanthine medium and increased levels of sAMP lyase were observed. In strain BFA2257 $\beta$ galactosidase activity driven by the pur promoter was assessed and shown to follow the same pattern of expression as purB. The increased sAMP lyase level indicates that BFA2257 suffers from a partial purine starvation. The lack of GAR synthetase activity indicates that transcription of the purD gene, which is located downstream of the pMutin1 insertion point in yexA, was markedly reduced. However, if IPTG was present, significant expression of purD was observed. This indicates that genes located downstream of yex $A$ were transcribed from the $\mathrm{P}_{\mathrm{spac}}$ promoter in the presence of IPTG. In strain HH309 the expression of both purB and purD genes responds as in wild-type cells to the addition of either xanthine or a mixture of adenine and guanosine, indicating normal transcriptional control of genes located downstream of yexA. The possibility could not be excluded that translation of the purQ gene located downstream of $y e x A$, and which has overlapping coding sequence with yex $A$, was affected by the pMutin insertion. However, strain $\mathrm{HH} 332$, which harbours the yexA6 allele in-frame deletion, was able to express the purD gene. This suggests normal transcription of genes located downstream of yexA. Because the reading frame of yexA6 is continuous and identical to the wild-type reading frame one would expect normal expression of the overlapping downstream purQ gene. Most likely both the pur $Q$ and purL genes, which encode subunits of 
Table 3. Level of FGAM synthetase activity in wild-type and yexA mutant strains as affected by PurQ, PurL and YexA

Cells were grown in glucose minimal medium as described in Table 2. Enzyme activities were determined as described in Methods.

\begin{tabular}{|c|c|c|c|c|c|}
\hline $\begin{array}{l}\text { Extract } \\
\text { no. }\end{array}$ & $\begin{array}{l}\text { Subunit contents of } \\
\text { the resulting extract }\end{array}$ & $\begin{array}{c}\text { FGAM } \\
\text { synthetase } \\
\text { activity } \\
\left(\text { nmol min }^{-1}\right. \\
\left.\text { mg }^{-1}\right)\end{array}$ & Source strain & $\begin{array}{l}\text { Relevant } \\
\text { genotype }\end{array}$ & $\begin{array}{l}\text { Addition to } \\
\text { growth medium }\end{array}$ \\
\hline 1 & PurQ PurL YexA & $3 \cdot 8$ & 168 & Wild-type & None \\
\hline 2 & PurQ PurL & $<0.05$ & HH309 & yexA6 & Xanthine \\
\hline 3 & PurQ PurL YexA & $1 \cdot 6$ & НH332 & yexA6 $\mathrm{P}_{\mathrm{spac}}-y e x A^{+}$ & IPTG \\
\hline 4 & YexA & $<0 \cdot 05$ & НH332 & yexA6 $\mathrm{P}_{\mathrm{spac}}-y e x A^{+}$ & Adenine + Guanosine + IPTG \\
\hline $2+4 *$ & PurQ PurL YexA & $1 \cdot 5$ & & & \\
\hline
\end{tabular}

*Equal amounts of cell extracts were present in the assay mixture.

the FGAM synthetase enzyme, are expressed and what is lacking for FGAM synthetase activity is the yex $A$ gene product.

\section{Complementation analysis}

To see if the yexA gene product could be supplemented in trans the yex $A$ gene was inserted in another location on the chromosome. Expression of yexA was put under the control of the $\mathrm{P}_{\text {spac }} / \mathrm{LacI}$ system by ligation of a PCR fragment containing yexA (Table 1) into plasmid pMutin1. The resulting plasmid, pHH1091, was transformed into strain HH330 (yexA6 amyE::pDG268neo) as described in Methods. The resulting strain $\mathrm{HH} 332$ [yexA6 amyE::pDG268neo::pHH1091 (yex $\left.A^{+}\right)$] (Fig. 2) required either IPTG or purine for growth and expressed both yex $A$ and lac $Z$ from the $\mathrm{P}_{\text {spac }}$ promoter. When cells were grown in minimal medium, $\beta$-galactosidase activity was increased when IPTG was added (Table 2). The lac $Z$ expression reflects the expression of yex $A$ in trans, which is built into the construction in front of the lacZ gene (see Fig. 2). It therefore was evident that YexA, when produced in trans, could complement the yexA6 deletion mutation.

Whether the YexA protein was required for FGAM synthetase activity in vitro was assessed in wild-type cells, in the yexA mutant strain HH309 and in strain $\mathrm{HH} 332$, in which the level of PurQ, PurL and YexA could be manipulated (Table 3). FGAM synthetase activity was found in strain 168, but not in strain HH309, which only produces the PurQ and the PurL protein. However, FGAM synthetase activity was found in strain HH322 when grown in the presence of IPTG. This was expected because of the way the construction was made. When adenine and guanosine were added together with IPTG to the growth medium no FGAM synthetase activity was found. Under these conditions the adenine and guanosine repress the expression of the pur operon and therefore also the synthesis of PurQ and PurL. However, when extracts of cells synthesizing
PurQ and PurL (extract 2, Table 3) and extracts of cells synthesizing YexA (extract 4, Table 3) were combined, FGAM synthetase activity was restored. These results prove that the yexA gene product is required for FGAM synthetase activity in $B$. subtilis and that yex $A$ therefore must be considered as a novel purine biosynthetic gene. We suggest that the yex $A$ gene is given the designation purS.

\section{DISCUSSION}

Since 1996 two research consortiums - a European and a Japanese - have performed systematic gene function analysis in B. subtilis (Vagner et al., 1998). One of the obligations for each of the research groups involved has been, in an assigned genomic region, to systematically inactivate all genes for which no obvious function could be suggested from the deduced amino acid sequence. The authors of this report were assigned the region sequenced by Borriss et al. (1996), which includes the pur operon. The function for 11 of the 12 genes of the pur operon has been identified from sequence similarity studies (Ebbole \& Zalkin, 1987) or by experimental means (Saxild \& Nygaard, 1988; Saxild et al., 1994). Only the function of the yex $A$ reading frame, which is located between purC and purQ, has remained unsolved. However, after publication of the nucleotide sequence, possible functions of yexA have been suggested. Ebbole \& Zalkin (1987) showed that the expression of yexA in E. coli gave rise to a small protein and they suggested a regulatory function of this protein. More recently, Peltonen \& Mäntsälä (1999) observed that reading frames similar to the yex $A$ gene exist in other bacteria and they suggested that the yex $A$ gene product was required for functional FGAM synthetase activity. However, they provided no experimental evidence to support this suggestion. In this report we demonstrate that a $B$. subtilis yexA mutant lacks FGAM synthetase activity and that it accumulates the substrate FGAR during purine starvation. We suggest that yex $A$ is 
renamed as purS. It appears that an extra peptide, PurS (YexA), is required for FGAM synthetase activity in bacteria like B. subtilis in which the enzyme is composed of heteromers. Since FGAM synthetase activity can be restored in vitro by adding extracts containing PurQ and PurL to an extract containing only PurS, we suggest that one possible role of PurS is to act as a hinge that links the two catalytic subunits. Another possibility is that PurS plays a role in catalysis. On the other hand we can exclude that PurS is required for stabilizing the PurQ and PurL subunits since we were able to synthesize biologically active PurQ and PurL proteins in the absence of PurS. yexA homologues most likely exist in cyanobacteria [Synechocystis sp. (accession no. Q55842)], methanogens [Methanococcus jannaschii (accession no. Q58988) and Methanobacterium thermoautotrophicum (accession no. 026271)] and the Grampositive bacteria Mycobacterium tuberculosis (accession no. AL123456), Mycobacterium leprae (accession no. 005755) and Lactococcus lactis (Peltonen \& Mäntsälä, 1999). These organisms all contain the multi-subunit form of FGAM synthetase encoded by purQ and purL genes that are similar to those found in B. subtilis.

\section{ACKNOWLEDGEMENTS}

We thank Jenny Christensen and Kirsten Hansen for excellent technical assistance. This research received financial support from the Saxild Family Foundation and the Novo Nordisk Foundation and was supported by EU contract BIO2-CT950278 .

\section{REFERENCES}

Barnes, T. S., Bleskan, J. H., Hart, I. M., Walton, K. A., Barton, J. W. \& Patterson, D. (1994). Purification of, generation of monoclonal antibodies to, and mapping of phosphoribosyl $\mathrm{N}$-formylglycine amidotransferase. Biochemistry 33, 1850-1860.

Birnboim, H. C. \& Doly, J. (1979). A rapid alkaline extraction procedure for screening recombinant plasmid DNA. Nucleic Acids Res 7, 1513-1523.

Borriss, R., Porwollik, S. \& Schroeter, R. (1996). The $52^{\circ}-55^{\circ}$ segment of the Bacillus subtilis chromosome: a region devoted to purine uptake and metabolism, and containing the genes $\cot A$, pabP and guaA and the pur gene cluster within a $34960 \mathrm{bp}$ nucleotide sequence. Microbiology 142, 3027-3031.

Boylan, R. J., Mendelson, N. H., Brooks, D. \& Young, F. E. (1972). Regulation of the bacterial cell wall: analysis of a mutant of Bacillus subtilis defective in biosynthesis of teichoic acid. J Bacteriol 110, 281-290.

Christiansen, L. C., Schou, S., Nygaard, P. \& Saxild, H. H. (1997). Xanthine metabolism in Bacillus subtilis: characterization of the $x p t-p b u X$ operon and evidence for purine- and nitrogencontrolled expression of genes involved in xanthine salvage and catabolism. J Bacteriol 179, 2540-2550.
Ebbole, D. J. \& Zalkin, H. (1987). Cloning and characterization of a 12-gene cluster from Bacillus subtilis encoding nine enzymes for de novo purine nucleotide biosynthesis. J Biol Chem 262, 8274-8287.

Ebbole, D. J. \& Zalkin, H. (1989). Bacillus subtilis pur operon expression and regulation. J Bacteriol 171, 2136-2141.

Hanahan, D. (1983). Studies on transformation of Escherichia coli with plasmids. J Mol Biol 166, 557-580.

Houlberg, U., Hove-Jensen, B., Jochimsen, B. \& Nygaard, P. (1983). Identification of the enzymatic reactions encoded by the purG and purI genes of Escherichia coli. J Bacteriol 154, 1485-1488.

Jensen, K. F., Houlberg, U. \& Nygaard, P. (1979). Thin-layer chromotographic methods to isolate ${ }^{32} \mathrm{P}$-labeled 5-phosphoribosyl- $\alpha-1$-pyrophosphate (PRPP): determination of cellular PRPP pools and assay of PRPP synthetase activity. Anal Biochem 98, 254-263.

Kunst, F., Ogasawara, N., Moszer, I. \& 148 other authors (1997). The complete genome sequence of the Gram-positive bacterium Bacillus subtilis. Nature 390, 249-256.

Miller, J. H. (1972). Assay of $\beta$-galactosidase. In Experiments in Molecular Genetics, pp. 352-355. Edited by J. H. Miller. Cold Spring Harbor, NY: Cold Spring Harbor Laboratory.

Peltonen, T. \& Mäntsälä, P. (1999). Isolation and characterization of a purC(orf)QLF operon from Lactobacillus lactis MG1614. Mol Gen Genet 261, 31-41.

Saxild, H. H. \& Nygaard, P. (1987). Genetic and physiological characterization of Bacillus subtilis mutants resistant to purine analogs. J Bacteriol 169, 2977-2983.

Saxild, H. H. \& Nygaard, P. (1988). Gene-enzyme relationships of the purine biosynthetic pathway in Bacillus subtilis. Mol Gen Genet 211, 160-167.

Saxild, H. H. \& Nygaard, P. (1991). Regulation of levels of purine biosynthetic enzymes in Bacillus subtilis: effects of changing nucleotide pools. J Gen Microbiol 137, 2387-2394.

Saxild, H. H., Jacobsen, J. H. \& Nygaard, P. (1994). Genetic and physiological characterization of a formate-dependent 5 '-phosphoribosyl-1-glycinamide transformylase activity in Bacillus subtilis. Mol Gen Genet 242, 415-420.

Saxild, H. H., Andersen, L. N. \& Hammer, K. (1996). dra$n u p C-p d p$ operon of Bacillus subtilis: nucleotide sequence, induction by deoxyribonucleosides, and transcriptional regulation by the $d e o R$-encoded DeoR repressor protein. J Bacteriol 178, 424-434.

Schendel, F. J., Mueller, E., Stubbe, J., Shiau, A. \& Smith, J. M. (1989). Formylglycinamide ribonucleotide synthetase from Escherichia coli: cloning, sequencing, overproduction, isolation, and characterization. Biochemistry 28, 2459-2471.

Vagner, V., Dervyn, E. \& Ehrlich, D. (1998). A vector for systematic gene inactivation in Bacillus subtilis. Microbiology 144, 3097-3104.

Received 29 October 1999; revised 10 December 1999; accepted 14 December 1999. 